\title{
PENGEMBANGAN AUGMENTED REALITY VERSI ANDROID SEBAGAI MEDIA PEMBELAJARAN SISTEM EKSKRESI MANUSIA
}

\author{
Qumillaila, Baiq Hana Susanti, dan Zulfiani \\ Fakultas Ilmu Tarbiyah dan Keguruan, UIN Syarif Hidayatullah Jakarta \\ email: qumillaila.syf@gmail.com
}

\begin{abstract}
Abstrak: Penelitian ini bertujuan untuk mengembangkan media pembelajaran biologi menggunakan teknologi augmented reality versi Android, serta menguji daya gunanya pada siswa dan guru biologi. Penelitian pengembangan ini terdiri atas tiga tahapan, yakni penelitian pendahuluan, pembuatan prototipe, serta refleksi sistematik dan dokumentasi. Data didapatkan melalui wawancara siswa dan guru, kuesioner, dan tes, sedangkan analisis data dilakukan dengan teknik deskriptif kualitatif dan statistik deskriptif. Penelitian ini menghasilkan produk berupa aplikasi AR versi Android untuk sistem ekskresi manusia yang mendapatkan skor rata-rata baik dalam validasi ahli, evaluasi kelompok kecil, dan uji lapangan, serta sangat baik dalam evaluasi satu-satu. Aplikasi AR versi Android ini dinilai menarik dan dapat diterima oleh siswa dan guru sebagai alternatif media pembelajaran untuk sistem ekskresi manusia, serta efektif dalam membantu proses pembelajaran biologi di kelas.
\end{abstract}

Kata kunci: android, augmented reality, sistem ekskresi manusia, penerimaan dan kemenarikans

\section{DEVELOPING ANDROID AUGMENTED REALITY AS A LEARNING MEDIA OF HUMAN EXCRETORY SYSTEM}

\begin{abstract}
This study aims to develop android Augmented Reality application as a learning media of human excretory system concept and to examine its practicality for biology students and teachers. This development research includes 3 stages, namely preliminary research, prototyping stage, and systematic reflection and documentation. The data were collected through interview to 100 students and 3 teachers, and questionnaires to 100 students and 3 teachers from three schools. This study has resulted in Android AR application for human excretory system concept which is rated "good" by expert review, small group evaluation and field study, and "very good" through one-to-one evaluation. This application is interesting for and is accepted by students and teachers as an alternative learning media for human excretory system concept, and is effective to help them in biology teaching-learning process.
\end{abstract}

Keywords: android, human excretory system, augmented reality, acceptance and attractiveness

\section{PENDAHULUAN}

Pemanfaatan teknologi dan media di dalam sebuah pembelajaran dapat membantu meningkatkan kualitas pembelajaran itu sendiri. Seperti yang dikatakan oleh Oemar Hamalik dalam Pribadi dan Katrin bahwa media dapat mengefektifkan komunikasi dan interaksi antara guru dan siswa dalam proses pendidikan dan pengajaran di sekolah (Pribadi \& Katrin, 2004:1.3). Terlebih lagi, perkembangan kurikulum yang ada hingga kini membuat guru untuk menerapkan pembelajaran yang berpusat kepada siswa. Dalam hal ini, para siswa bisa memanfaatkan teknologi dan media dalam serangkaian cara untuk meningkatkan belajar (Smaldino, et al., 2011:12)
Hingga saat ini, teknologi komunikasi dan informasi terus mengalami perkembangan pesat yang diikuti dengan perubahan pola hidup masyarakat, namun perkembangan ini dirasakan belum mampu memenuhi kebutuhan media pembelajaran yang sesuai dengan kedinamisan pola hidup tersebut. Hasil wawancara peneliti dengan 3 orang guru biologi SMA di Jakarta Selatan menunjukkan bahwa mereka saat ini membutuhkan media pembelajaran yang mengikuti perkembangan teknologi, yang cenderung dapat diterima oleh para siswa, seperti gambar 3D, video, animasi, dan teknologi yang memanfaatkan perangkat mobile dan bersifat interaktif. Sedangkan menurut penelitian Primasari, media berupa laptop, LCD, dan Power Point merupakan media 
yang paling banyak digunakan dalam kegiatan belajar mengajar oleh guru biologi (Primasari, 2014:52). Lebih lanjut lagi, para guru dan siswa menyatakan bahwa mereka lebih sering memanfaatkan teknologi media pembelajaran berupa Power point, yang diakui oleh $48,15 \%$ siswa bahwa media tersebut tidak variatif, sehinggga membutuhkan bantuan media lain yang dapat membuat suasana belajar biologi menjadi lebih menarik. Selain itu, media yang digunakan ini masih terbatas pada lokasi pembelajaran dan tidak mobile, sehingga media tersebut hanya dapat digunakan oleh siswa di ruang kelas.

Kemajuan teknologi yang pesat juga membawa perkembangan pada ilmu pengetahuan, tidak terkecuali biologi. Hal ini tentu mendorong para pengajar biologi untuk terus melakukan inovasi dan upaya-upaya dalam memanfaatkan hasil-hasil teknologi dalam proses pembelajaran. Menurut Hasrudin, materi biologi dapat dipandang sebagai sesuatu yang sederhana, namun juga dapat dipandang sebagai sesuatu yang rumit dan kompleks (Hasruddin,2009:149). Salah satu materi yang dianggap sulit untuk dipahami oleh para siswa, menurut penelitian Aprilianti adalah materi sistem ekskresi manusia karena sistem eksresi mencakup subbab yang cukup banyak (Aprilianti, 2013:1). Hal serupa juga diungkapkan oleh guru biologi di SMAN 28 Jakarta, berdasarkan hasil wawancara peneliti, materi sistem ekresi merupakan salah satu materi biologi yang tidak mudah dipahami oleh siswa, terutama materi tentang ginjal. Hal ini dikarenakan materi sistem eksresi pada manusia berisikan serangkaian proses yang terjadi di dalam tubuh manusia dan melibatkan organ-organ dalam tubuh yang sulit untuk dijelaskan tanpa menggunakan alat atau teknologi yang mendukung. Oleh sebab itu, dibutukan alat atau teknologi yang dapat menggambarkan materi tersebut secara representatif.

Pesatnya kemajuan teknologi ini telah menyentuh berbagai kalangan termasuk pelajar. Oleh karena perubahan tersebut, menurut Dede, karakteristik para peserta didik pun terus berkembang, seperti dalam hal keterampilan, dan bidang keahlian dan pengetahuan yang bernilai di masyarakat (Yuen, et al., 2011:132). Salah satu hasil teknologi yang sedang mengalami perkembangan, terutama di kalangan pelajar adalah teknologi komunikasi. Pada situs teknojurnal.com, terdapat data yang dikeluarkan oleh Nielsen Company Indonesia tahun 2010 yang menunjukkan bahwa peng- guna handphone tertinggi berasal dari golongan anak muda dengan rentangan usia 15-19 tahun. Peningkatan pengguna handphone di kalangan pelajar menduduki tempat ke dua setelah kalangan pekerja kasar (Blue Collar). Sedangkan menurut hasil wawancara dengan guru biologi SMAN 28 Jakarta, media pembelajaran yang ada saat ini tidak seimbang dengan kemajuan teknologi yang begitu pesat sehingga media tersebut dinilai tidak lagi efektif untuk menunjang pembelajaran.

Di sisi lain, perkembangan teknologi yang pesat saat ini telah melahirkan suatu teknologi augmented reality. Augmented reality, atau yang biasa disingkat AR, merupakan sebuah teknologi yang dapat menggabungkan suatu objek 3D ke dalam lingkungan nyata menggunakan media webcam. Teknologi ini kini telah banyak dikembangkan di negara-negara maju untuk berbagai keperluan termasuk keperluan pendidikan. Menurut hasil penelitian Malinka Ivanova dan Georgi Ivanov, penggunaan AR sebagai media pembelajaran mampu membantu siswa untuk memahami konsep dan teori, menstimulasi siswa untuk berfikir secara konseptual dan merasakan $3 \mathrm{D}$, meningkatkan gambaran (representasi) dan persepsi, menciptakan suasana belajar yang interaktif dan atraktif serta lebih menyenangkan (Ivanova \& Ivanov, 2011: 176, 183).

Teknologi AR sebagai media dalam pembelajaran memiliki beberapa keunggulan.AR memungkinkan konten digital (audio, video, objek 2D dan 3D) untuk terlihat menyatu dengan dunia nyata melalui suatu perangkat (device). AR juga memungkinkan pembelajaran konten dalam bentuk tiga dimensi (3D), sehingga dapat memvisualisasikan hal-hal yang sulit dilihat, selain itu, kemampuan AR untuk menghadirkan objek virtual ke dunia nyata secara realtime dapat mengaktifkan rasa keberadaan, kedekatan, dan penyelaman pada peserta didik. Menurut Yuen et al., penambahan ini dapat membantu dan meningkatkan pengetahuan serta pemahaman individu mengenai kejadian yang berlangsung di sekitarnya (Yuen, et al., 2011:119). Lebih lagi, mobile $A R$ memungkinkan pembelajaran di mana saja, kolaboratif dan disituasikan, sehingga dapat menjembatani pembelajaran formal dan informal.

Teknologi AR menggalami perkembangan dengan cepat dan hingga kini AR telah dikembangkan pada perangkat sistem operasi Android dan iPhone, yang memiliki fitur-fitur navigasi 
yang mendukung AR. Sejak berkembangnya teknologi AR yang kini dapat diimplementasikan pada perangkat yang populer, seperti pada mobile platform (iOS dan Android), peluang AR untuk diakses oleh masyarakat termasuk pelajar menjadi terbuka. Pemanfaatan teknologi AR pada perangkat seperti smartphone yang akrab di kalangan para siswa dapat dijadikan suatu alternatif untuk mengembangkan media pembelajaran yang inovatif dan dapat diterima oleh siswa.

Seiring dengan pesatnya perkembangan persebaran perangkat smartphone di masyarakat, tidak terkecuali di kalangan pelajar, kini penelitian tentang penggunaan AR telah banyak difokuskan untuk pembelajaran mobil (mobile learning), di mana siswa tidak dibatasi dengan PC di suatu ruang tetap akan tetapi pembelajaran bisa dilakukan secara dinamis. Penggunaan teknologi AR pada ponsel dapat menunjang mobilitas pengguna dan memungkinkan siswa untuk dapat melakukan kegiatan pembelajaran di mana saja. Terlebih lagi keberadaan perangkat mobile dengan bersistem operasi Android misalnya, telah dekat dengan siswa dalam kesehariannya. Menurut hasil penelitian pendahuluan pada 100 siswa dari 3 SMA di Jakarta Selatan, $65.90 \%$ siswa merupakan pengguna smartphone Android, dan 57.32\% siswa rata-rata menghabiskan waktu lebih dari 4 jam sehari dengan Android.

Android merupakan suatu sistem operasi (OS) untuk perangkat mobile berbasis Linux yang mencakup sistem operasi, middleware dan aplikasi merupakan platform open source yang memungkinkan para pengembang untuk membuat aplikasi secara mudah serta dapat digunakan oleh bermacam perangkat bergerak (mobile device). Menurut data yang dikeluarkan oleh StatCounter Global Stats, Android merupakan sistem operasi yang mengalami perkembangan pengguna tertinggi di antara delapan sistem operasi teratas lainnya di Indonesia pada kurun waktu Desember 2012 sampai dengan Desember 2013 (StatCounter Global Stats, 2014).

Penelitian terkait AR baik dalam hal pengembangan, penerimaan maupun efektivitasnya dalam pendidikan terus dilakukan. Beberapa penelitian terdahulu menunjukkan bahwa AR memiliki potensi yang baik dalam pendidikan. Chen et al. mengembangkan AR untuk menyediakan para pelajar media yang mudah dioperasikan, ber-interface yang interaktif dan beragam, serta menarik untuk merangsang motivasi intrinsik dan hasil belajar (Chen, et al., 2013: 1). Chi-Yin Yuen et al. memeriksa penelitian-penelitian terbaru tentang perkembangan AR. Berdasarkan temuannya, jumlah peneliti dan pengembang di bidang AR meningkat, dan pada tahun-tahun terakhir, pertumbuhan dan kemajuan pada AR telah signifikan (Chen, et al., 2013:122).

Lebih lanjut, Chi-Yin Yuen et al. juga mengevaluasi implikasi AR untuk pembelajaran dan pendidikan. Hasilnya adalah, menurut Dede et al. dan Saenz, AR telah memberikan pengaruh positif pada pendidikan, yakni meningkatkan prestasi individual dalam pembelajaran macam-maam kemampuan fisik. Meskipun baru dan menarik, konten AR masih cukup sulit untuk dibuat dan disebarkan, terutama oleh para guru dan siswa karena hal ini membutuhkan pengetahuan teknis yang signifikan (Chen, et al., 2013:133). Namun, perusahaan-perusahaan terusmengembangkan peralatan pengembangan AR yang lebih mudah. Oleh sebab itu,sebaiknya terus dilakukan penelitian untuk mengembangkan AR dan mengevaluasi implikasinya terhadap pembelajaran dan pendidikan.

\section{METODE}

Poses penelitian pengembangan media augmented reality versi Android untuk konsep sistem eksresi, secara umum, terdiri atas empat tahapan dan telah melalui 2 tahapan, yakni penelitian pendahuluan, dan tahapan prototipe. Tahapan evaluasi sumatif tidak dilakukan pada penelitian ini.Sedangkan tahap keempat, yang merupakan tahap terakhir dari penelitian pengembangan ini adalah refleksi sistematik dan dokumentasi (systematic reflection and documentation).Gambar 1 menunjukkan alur penelitian pengembangan.

Pada tahap Penelitian pendahuluan, penentuan tujuan, konsep, responden, dan materi dilakukan. Untuk menentukan materi atau isi yang akan dirancang pada media, dilakukan penelaahan kurikulum sehingga materi pada media sesuai dengan materi yang tertuang pada kurikulum.

Pada tahap prototipe, untuk membuat aplikasi ini, software Blender versi 2.69, Unity dan Vuforia AR Extension for Unity digunakan. Aplikasi ini dibuat untuk digunakan menggunakan perangkat smartphone dengan sistem operasi Android.Perancangan desain media selanjutnya dilakukan pada storyboard.Setelah desain selesai dirancang pada storyboard, tahap perancangan aplikasi augmented reality ini selanjutnya adalah 


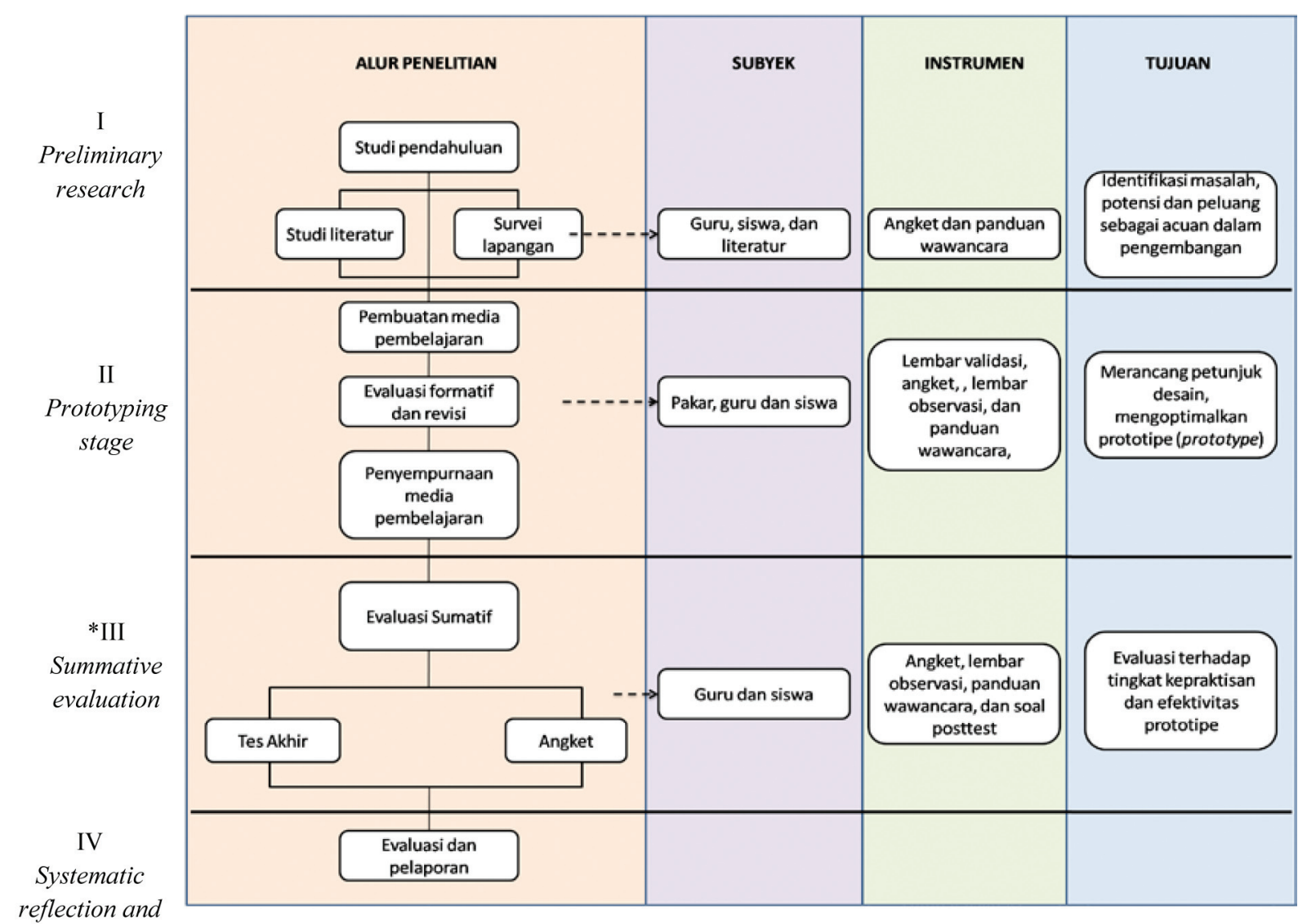

*tahap evaluasi sumatif (summative evaluation) tidak dilakukan oleh peneliti

\section{Gambar 1. Diagram Gambaran Alur Penelitian Pengembangan}

pembuatan objek sistem eksresi pada manusia ke dalam bentuk tiga dimensi dengan menggunakan software Blender versi 2.69. Terdapat enam buah objek yang dibuat untuk aplikasi ini, yakni organ ekskresi manusia, ginjal, struktur ginjal, tipe nefron, susunan nefron, dan proses pembentukan urin.

Setelah dibuat, selanjutnya objek-objek tersebut dieskport sehingga file disimpan dalam format .fbx. Tahap selanjutnya adalah menentukan gambar untuk dijadikan marker. Gambar yang akan dijadikan marker selanjutnya diupload ke website qualcomm developer. Marker yang sudah didaftarkan tersebut selanjutnya diunduh dengan format unitypackage. Model tiga dimensi dengan fomat .fbx, library Qcard, dan marker dengan format unitypackage yang telah diunduh diimport ke dalam software unity 3D.aplikasi selanjutnya dibuild menggunakan Android SDK dan disimpan dalam format .apk.Tahap perancangan aplikasi dapat dilihat pada gambar 2 .

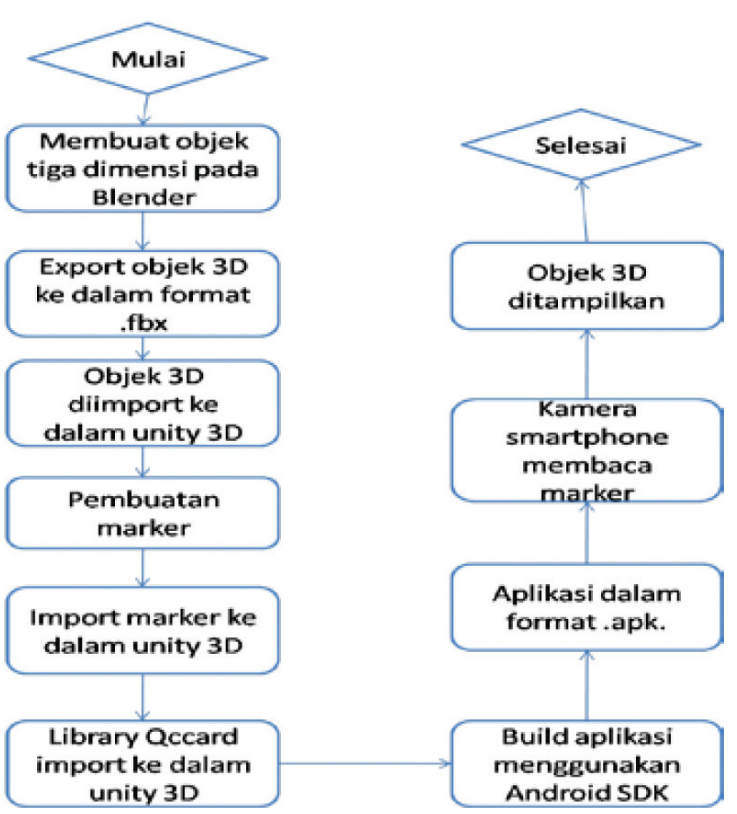

Gambar 2. Diagram Alur Perancangan Aplikasi AR

Prototipe media pembelajaran AR berbasis Android utnuk sistem ekskresi manusia yang telah dibuat selanjutnya diuji validitasnya 
melalui evaluasi formatif, melalui empat tahapan menurut Martin Tessmer, yakni pemeriksaan ahli (expert review), evaluasi satu-satu, uji kelompok kecil, dan uji lapangan (Zulkardi,2015:3-4). Berdasarkan pemeriksaan ahli materi dan media, prototipe dinyatakan valid karena mendapatkan rata-rata skor 4 yang berarti aspek-aspek yang tercakup materi dan pada media ini dinilai baik. Hasil dari evaluasi ini selanjutnya dinamakan prototipe kedua. Berdasakan evaluasi satu-satu dan kelompok kecil, media tersebut sangat praktis karena mendapatkan rata-rata skor 5, atau sangat baik. Prototipe kedua diujicobakan ke subyek penelitian, melalui uji lapangan yang dilakukan pada sebanyak 100 orang siswa dan 3 orang guru dari tiga sekolah berbeda. Produk yang diujicoba lapangan telah memenuhi kriteria validitas dan kepraktisan.

Subyek uji coba produk ini terdiri dari pakar di bidang isi produk, ahli di bidang perancangan produk, dan sasaran pengguna produk. Pakar ahli di bidang isi dan produk memenuhi kualifikasi keahlian tingkat S1.Sasaran pengguna produk meliputi guru dan siswa tingkat SMA di Jakarta Selatan dengan kualifikasi sekolah berakreditasi A.

Lembar observasi berbentuk checklist, pedoman wawancara, buku catatan, kamera, perekam suara, angket yang digunakan dengan skala Likert, dan soal posttest digunakan untuk mengambil data pada penelitian ini.

Data yang diperoleh dari hasil wawancara, observasi, dan dokumentasi dianalisis, disintesis, dan ditarik kesimpulan sehingga data dapat mudah dipahami. Data mentah yang akan diperoleh dari rating scale (teknik angket) adalah berupa angka kemudian ditafsirkan dalam pengertian kualitatif. Tes akhir untuk setiap butir soal yang dijawab benar mendapatkan skor 1, sedangkan soal yang salah atau tidak dijawab mendapatkan skor 0 . Selanjutnya, skor dan nilai dari setiap responden dihitung dan dicarikan hasil perhitungan statistik deskriptif seperti rata-rata, modus, dan nilai tengah.

\section{HASIL}

Aplikasi ini menggunakan enam buah marker (Gambar 3) yang masing-masing marker-nya akan menampilkan enam model yang berbeda-beda.

\section{objek $\begin{gathered}\text { dengan } \\ \text { organ }\end{gathered}$ \\ yang akan \\ dimunculkan \\ Gambar 3. Contoh Marker Aplikasi AR Android Sistem Ekskresi Manusia}

Ketika kamera smartphone Android diarahkan ke salah satu marker, maka akan muncul objek organ ginjal manusia sesuai dengan label objek pada marker dan tombol keterangan. Keenam model tersebut antara lain berlabel sistem eksresi manusia, ginjal, susunan ginjal, tipe nefron, susunan nefron, dan proses pembentukan urin(gambar 4).
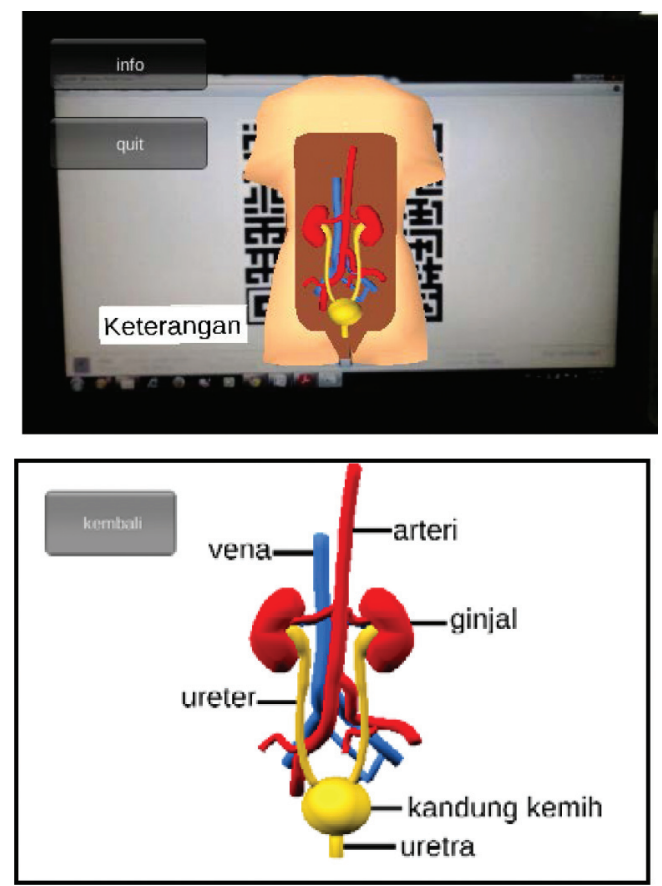

Gambar 4. Contoh Tampilan Objek AR Organ Ekskresi Manusia (atas) dan Menu Keterangan (bawah)

Aspek-aspek dari media yang diuji pada tahap Uji lapangan ini meliputi kemampuan untuk dapat dilaksanakan (implementability), kesinambungan (sustainability), kecocokan dengan lingkungan (appropriateness), penerimaan dan kemenarikan (acceptance and attractiveness), 
dan efektivitas (effectiveness). Respon siswa dan guru menunjukkan bahwa rata-rata hasil yang diperoleh dari setiap aspek ialah baik.

\section{Kemampuan untuk dapat Dilaksanakan}

Pada aspek kemampuan untuk dapat dilaksanakan, terdapat empat item pernyataan, dengan rata-rata siswa menyatakan setuju bahwa aplikasi AR versi Android untuk sistem ekskresi manusia ini dapat digunakan dengan baik dalam pembelajaran biologi. Hasil tersebut dapat dilihat pada Gambar 5.

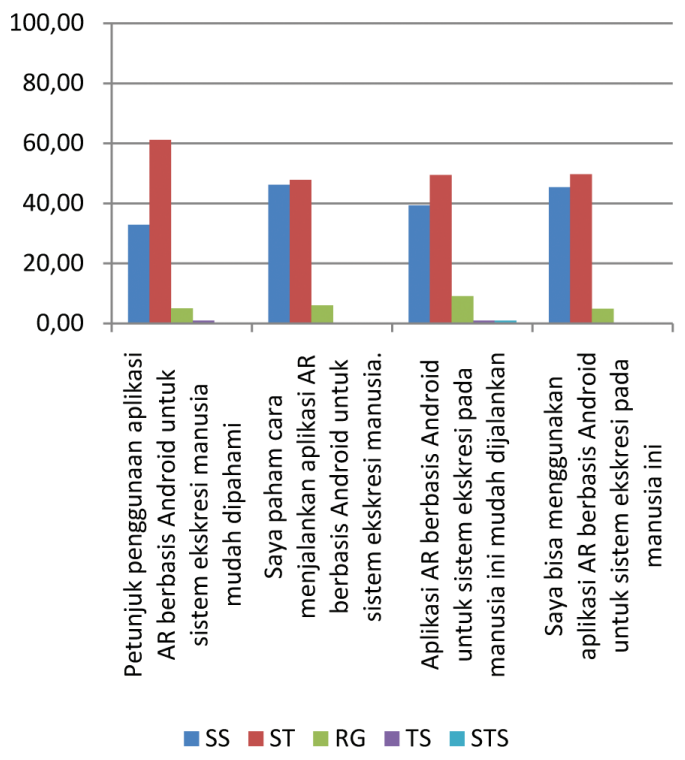

Gambar 5. Grafik Analisis Angket Respon Siswa tentang Kemampuan untuk Dilaksanakan Aplikasi AR Versi Android (siswa, $n=100$ ). Angka yang tertera dinyatakan dalam persen $(\%)$

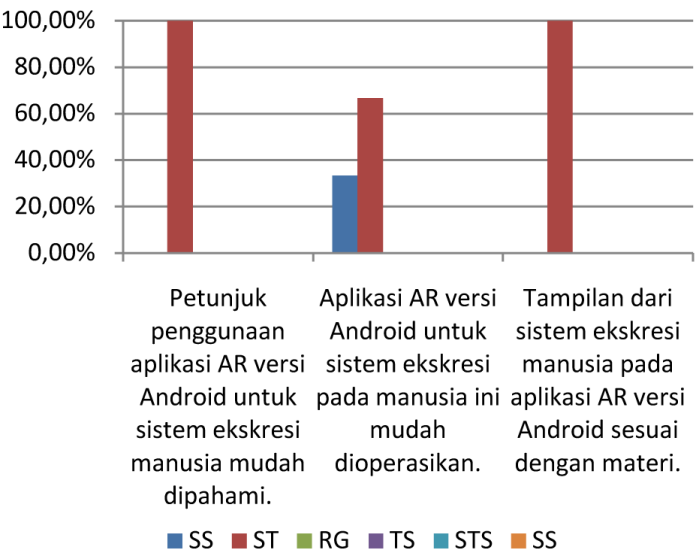

Gambar 6. Grafik Angket Respon Guru tentang Kemampuan untuk Dilaksanakan dari AR Versi Android ( $n=3$ ). Angka yang Ditunjukan Dinyatakan dalam persen (\%)
Pada 3 item pernyataan, rata-rata guru menyatakan setuju bahwa aplikasi AR versi Android untuk sistem ekskresi manusia ini sesuai dengan materi, mudah untuk dioperasikan, dan mudah dipahami. Hasil tersebut dapat dilihat pada gambar 6.

\section{Kesinambungan}

Gambar 7 menunjukkan bahwa pada aspek kesinambungan, dari 8 item pernyataan, rata-rata siswa menyatakan setuju bahwa aplikasi AR versi Android untuk sistem ekskresi manusia ini memiliki keberlanjutan yang baik untuk dapat digunakandalam pembelajaran biologi dalam beberapa jangka waktu ke depan.

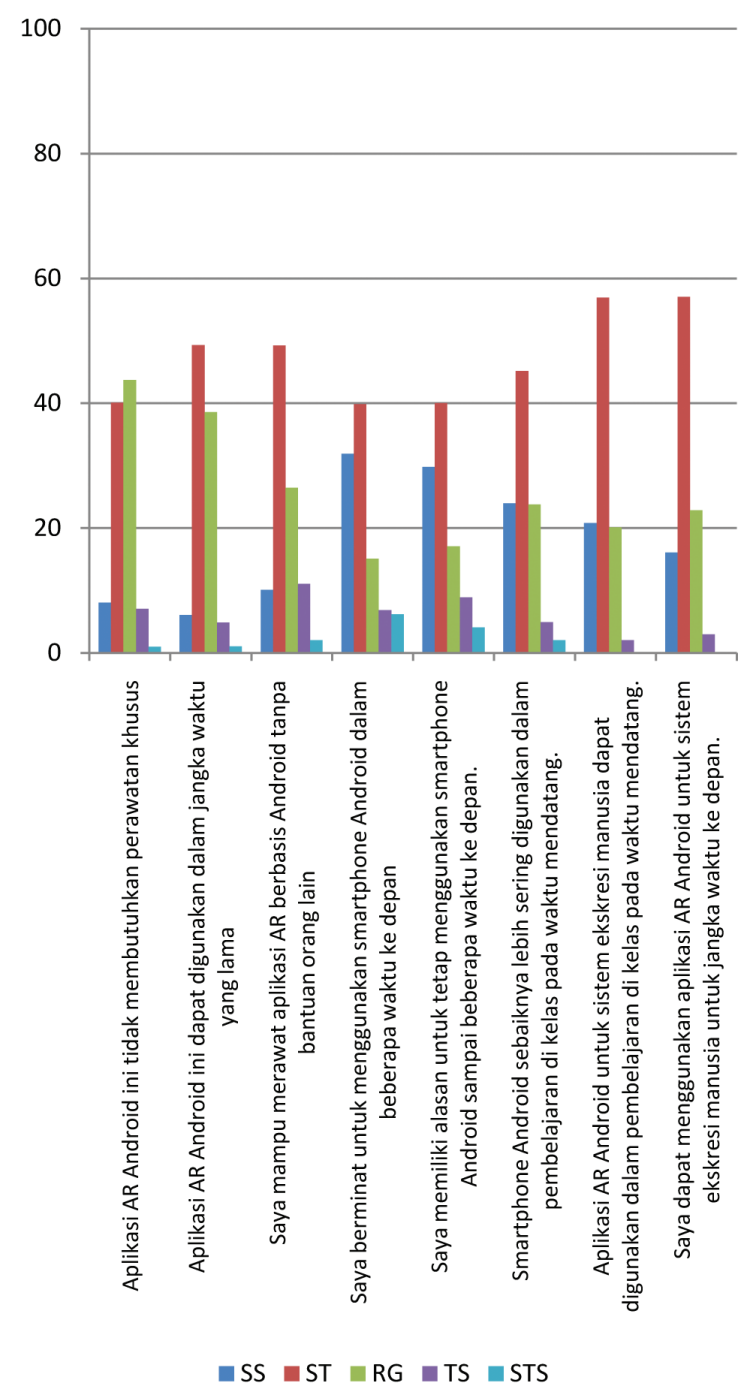

Gambar 7. Grafik Analisis Angket Respon Siswa tentang Kesinambungan Aplikasi AR Versi Android (siswa, $n=100$ ). Angka yang tertera Dinyatakan dalam persen (\%)

Pada 3 item pernyataan, rata-rata guru menyatakan tidak setuju bahwa guru mendapat 
kesulitan dalam hal perawatan dan pemeliharaan Aplikasi AR versi Android untuk sistem ekskresi manusia ini, dan bahwa konten atau isi media ini akan kadaluwarsa dalam beberapa waktu ke depan. Para guru rata-rata menyatakan sangat setuju bahwa para guru dapat menyesuaikan penggunaan aplikasi AR versi Android untuk konsep sistem eksresi manusia ini dengan kebutuhan di lapangan (gambar 8).

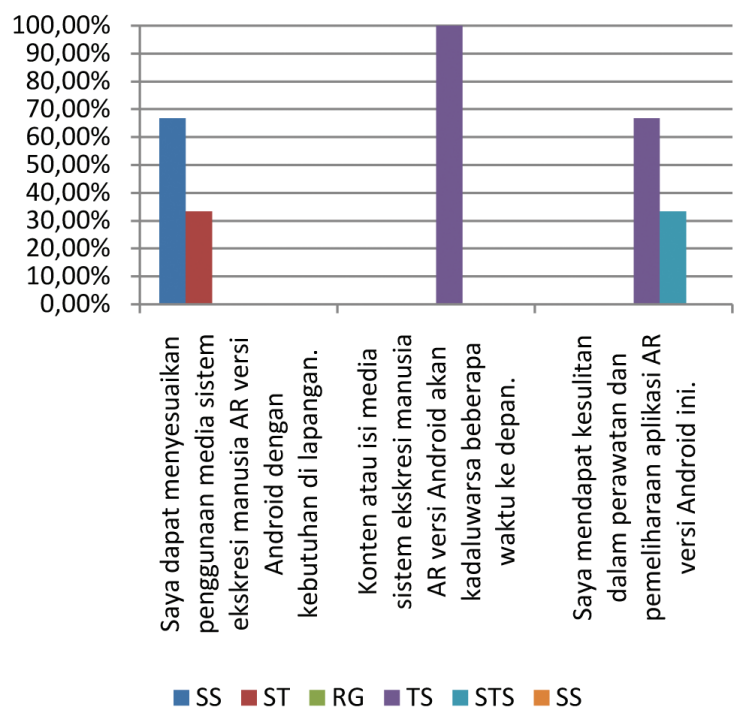

Gambar 8. Grafik Angket Respon Guru tentang Kesinambungan dari AR versi Android (n=3). Angka yang Ditunjukan Dinyatakan dalam persen (\%)

\section{Kecocokan dengan lingkungan}

Pada aspek kecocokan dengan lingkungan, terdapat 4 item pernyataan, dengan rata-rata siswa menyatakan setuju bahwa aplikasi AR versi Android untuk sistem ekskresi manusia ini sesuai unuk digunakan dalam lingkungan pembelajaran biologi. Hasil tersebut dapat dilihat pada Gambar 9.

Pada aspek kecocokan dengan lingkungan, terdapat 4 item pernyataan, dengan rata-rata guru menyatakan setuju bahwa aplikasi AR versi Android untuk sistem ekskresi manusia ini dapat digunakan untuk merancang situasi belajar secara klasikal maupun individual. Namun demikian, ketiga guru berbeda pendapat mengenai penyesuaian media tersebut dengan berbagai model pembelajaran, masing-masing menjawab setuju, ragu-ragu, dan tidak setuju. Hasil tersebut dapat dilihat pada Gambar 10.

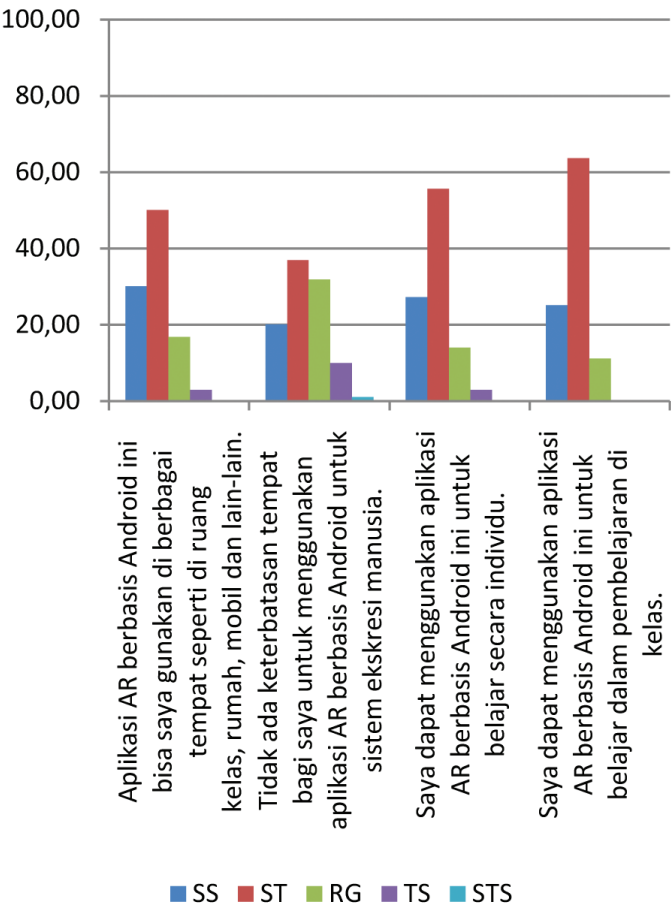

Gambar 9. Grafik Analisis Angket Respon Siswa tentang Kecocokan dengan Linggkungan Aplikasi AR Versi Android (siswa, $n=100$ ). Angka yang tertera

Dinyatakan dalam persen (\%)

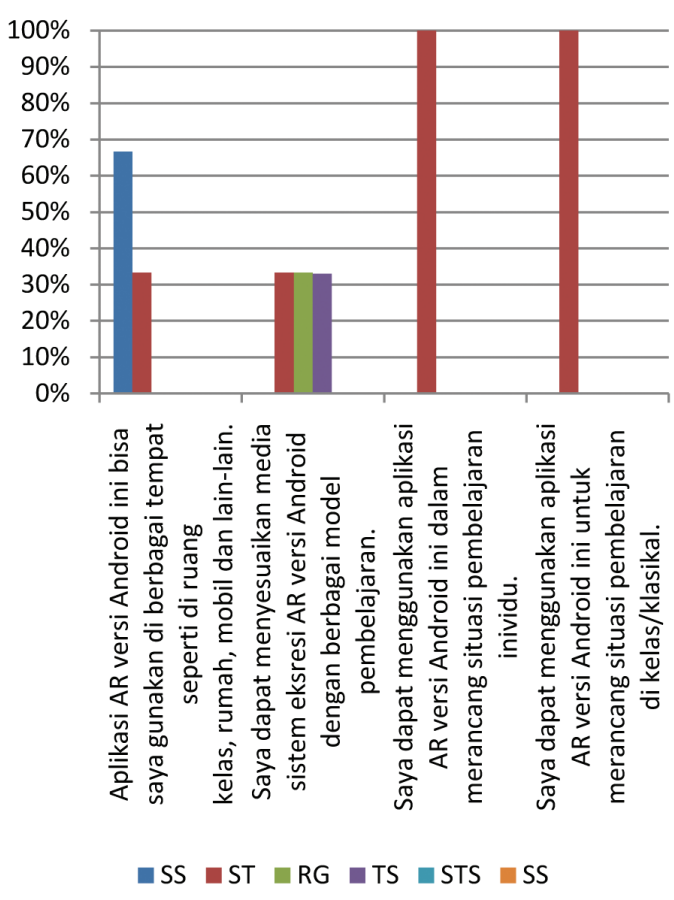

Gambar 10. Grafik Angket Respon Guru tentang Kecocokan dengan Lingkungan dari AR versi Android (n=3). Angka yang ditunjukan dinyatakan dalam persen $(\%)$ 


\section{Penerimaan dan kemenarikan}

Pada gambar 11, terlihat bahwa pada 8 item pernyataan, rata-rata siswa menyatakan setuju bahwa Aplikasi AR versi Android untuk sistem ekskresi manusia ini dapat diterima dan menarik untuk digunakan dalam pembelajaran biologi.

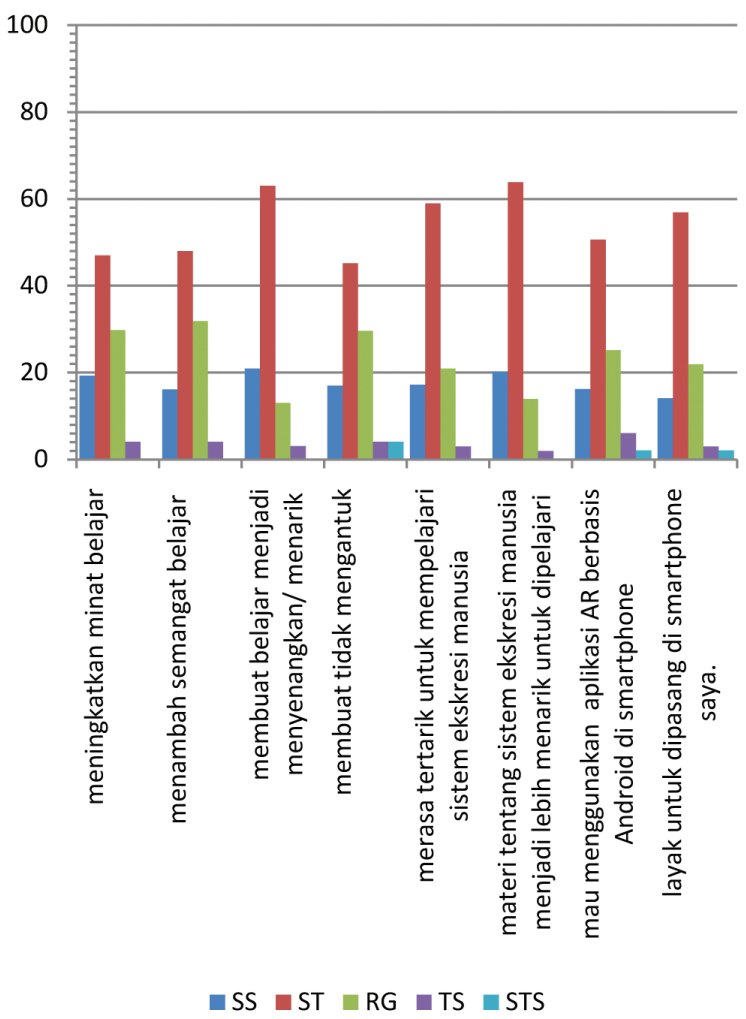

Gambar 11. Grafik Analisis Angket Respon Siswa tentang Kemenarikan dan Penerimaan Aplikasi AR versi Android (siswa, $n=100$ ). Angka yang tertera Dinyatakan dalam persen $(\%)$

Pertanyaan terbuka juga diajukan kepada para siswa untuk mengetahui hal-hal yang mendukung bagi aplikasi AR berbasis Android ini untuk digunakan di dalam kelas. Secara umum, para siswa berpendapat bahwa aplikasi ini dapat digunakan dalam pembelajaran biologi di dalam kelas setidaknya karena lima hal yang dapat dilihat pada gambar 12 .

Selanjutnya, pertanyaan terbuka juga diajukan untuk mengetahui lebih lanjut hal-hal yang dianggap menarik oleh siswa pada aplikasi AR berbasis Android untuk sistem ekskresi manusia. Mereka menjawab bahwa gambar 3D (65\%), penggunaan marker yang dapat memunculkan gambar 3D (23\%), animasi (10\%), dan musik latar (backsound) (4\%) merupakan hal menarik yang terdapat pada aplikasi AR berbasis Android untuk sistem ekskresi manusia (Gambar 13).

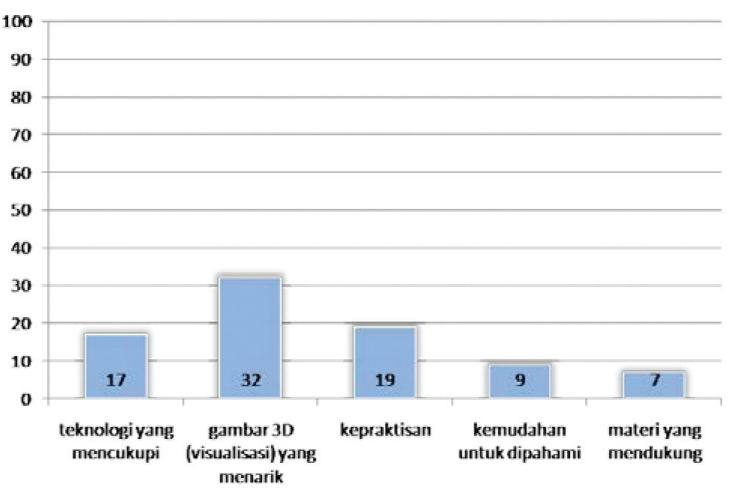

Gambar 12. Hasil analisis jawaban siswa dengan pertanyaan: "Hal-hal apa saja yang mendukung aplikasi AR Android tersebut untuk digunakan di dalam kelas?" $(n=100)$. Persentase (frekuensi relatif) berdasarkan total jumlah jawaban yang diberikan, angka pada batang merupakan frekuensi sebenarnya.

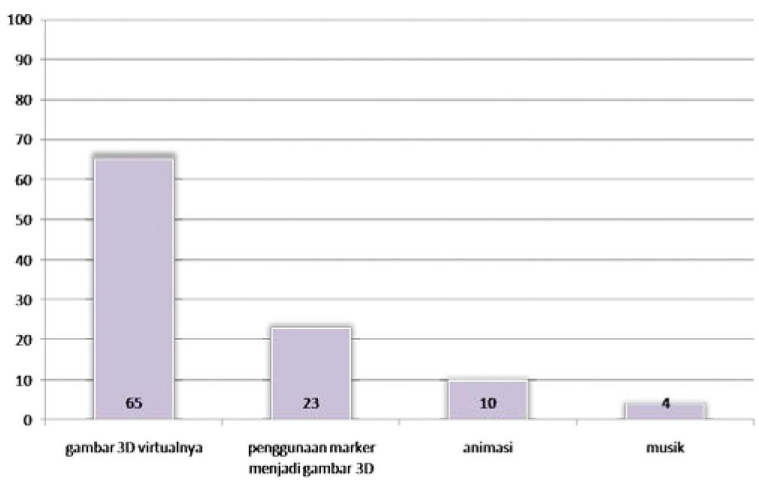

Gambar 13. Hasil analisis jawaban siswa dengan pertanyaan: "Bagian manakah dari AR android tersebut yang menarik?" $(n=100)$. Persentase (frekuensi relatif) berdasarkan total jumlah jawaban yang diberikan, angka pada batang merupakan frekuensi sebenarnya.

Pada aspek penerimaan dan kemenarikan, rata-rata guru menyatakan setuju bahwa media sistem ekskresi AR versi Android dapat menjadi solusi alternatif multimedia pembelajaran tentang sistem ekskresi pada manusia. Rata-rata mereka menyatakan sangat setuju bahwa aplikasi ini dapat membantu mereka untuk mengajarkan siswa tentang subyek dari pengalaman nyata yang tidak dapat diperoleh siswa secara langsung. Hasil tersebut dapat dilihat pada Gambar 14. 


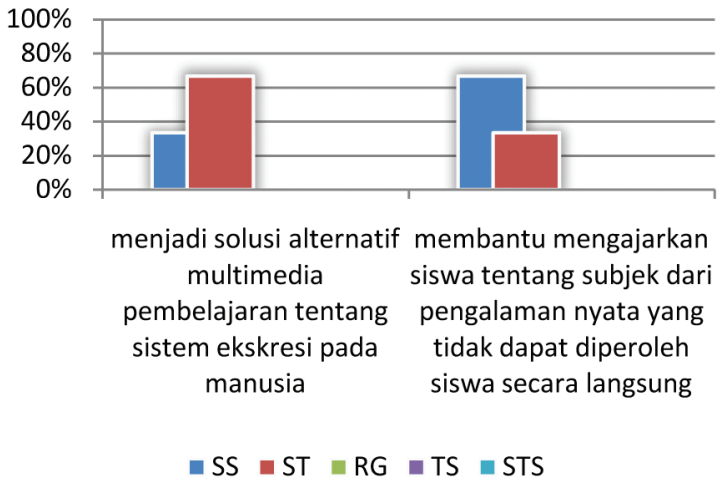

Gambar 14. Grafik Analisis Angket Respon Guru tentang Kemenarikan dan Penerimaan Aplikasi AR versi Android (n=3). Angka pada batang merupakan frekuensi sebenarnya

Selanjutnya, untuk mendapatkan informasi lebih jauh terkait hal-hal yang mendukung aplikasi AR versi Android untuk sistem ekskresi ini agar bisa digunakan di dalam pembelajaran biologi di kelas, serta hal-hal yang dianggap menarik oleh para guru, pertanyaan terbuka juga diajukan. Adapun tanggapan mereka terkait dua hal tersebut dapat dilihat pada Tabel 1.

\section{Efektivitas}

Rincian item pernyataan dan hasil analisis aspek efektivitas penggunaan media AR versi Android untuk konsep sistem ekskresi manusia ditunjukkan pada Gambar 15.Dapat dilihat bahwa pada 6 item pernyataan, rata-rata siswa menyatakan setuju bahwa Aplikasi AR versi Android untuk sistem ekskresi manusia ini efektif untuk digunakan dalam pembelajaran biologi.

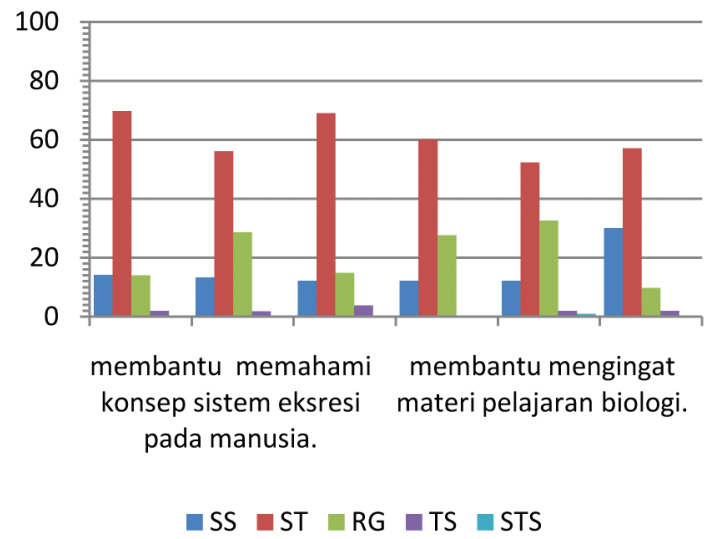

Gambar 15. Grafik Angket Respon Siswa tentang Efektivitas AR versi Android $(n=100)$. Angka yang Ditunjukan Dinyatakan dalam persen $(\%)$

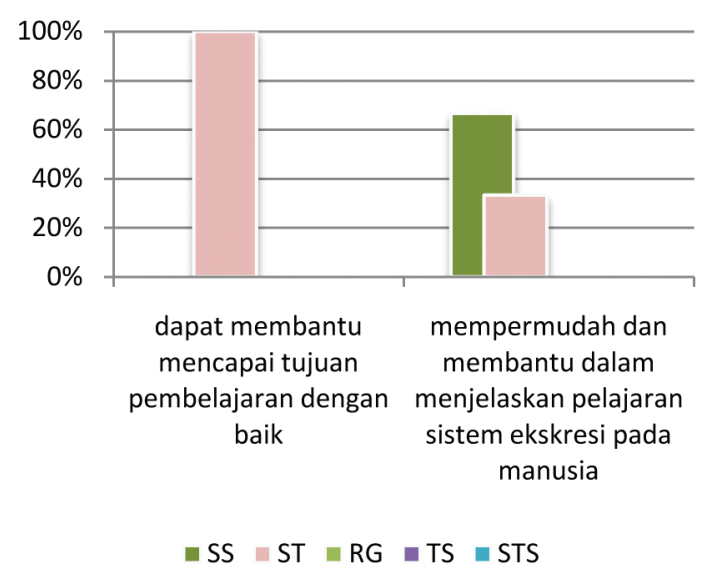

Gambar 16. Grafik Angket Respon Guru tentang Efektivitas AR versi Android ( $(n=3)$. Angka pada Batang merupakan Frekuensi Sebenarnya

Tabel 1. Respon Guru tentang Kemenarikan dan Penerimaan Aplikasi AR versi Android

\begin{tabular}{|c|c|c|c|}
\hline \multirow{2}{*}{ Pertanyaan } & \multicolumn{3}{|c|}{ Jawaban Guru } \\
\hline & 1 & 2 & 3 \\
\hline $\begin{array}{l}\text { Hal-hal apa sajakah yang } \\
\text { mendukung aplikasi AR versi } \\
\text { Android sistem ekskresi } \\
\text { manusia tersebut untuk } \\
\text { digunakan di dalam kelas? }\end{array}$ & $\begin{array}{l}\text { Menarik } \\
\text { siswa untuk } \\
\text { belajar }\end{array}$ & $\begin{array}{l}\text { Pemanfaatan } \\
\text { fasilitas IT yang } \\
\text { dimiliki siswa/guru } \\
\text { sebagai media } \\
\text { pembelajaran }\end{array}$ & $\begin{array}{l}\text { Peserta didik } \\
\text { dapat melihat } \\
\text { objek dengan jelas } \\
\text { sampai pada } \\
\text { proses }\end{array}$ \\
\hline $\begin{array}{l}\text { Bagian manakah dari aplikasi } \\
\text { AR versi Android untuk } \\
\text { sistem ekskresi manusia } \\
\text { tersebut yang menarik bagi } \\
\text { Bapak/Ibu? }\end{array}$ & $\begin{array}{l}\text { Gambarnya } \\
\text { yang menarik } \\
\text { siswa }\end{array}$ & $\begin{array}{l}\text { Penggunaan marker } \\
\text { untuk melihat } \\
\text { gambar-gambar } 3 \\
\text { dimensi }\end{array}$ & $\begin{array}{l}\text { Contoh nefron dan } \\
\text { proses } \\
\text { pembentukan urin }\end{array}$ \\
\hline
\end{tabular}


Pada aspek efektivitas, para guru juga menyatakan sangat setuju bahwa media sistem ekskresi AR versi Android dapat membantu mereka untuk mencapai tujuan pembelajaran dengan baik.Namun, rata-rata mereka menyatakan ragu bahwa aplikasi ini mempermudah dan membantu mereka dalam menjelaskan pelajaran sistem ekskresi pada manusia. Hasil respon guru ini dapat lebih jelas dilihat pada Gambar 16.

\section{Pembahasan \\ Penelitian Pendahuluan}

Hasil Penelitian pendahuluan menunjukkan bahwa peran media pembelajaran, berdasarkan wawancara, diakui oleh rata-rata siswa (48.15\%) dapat membantu mereka dalam proses belajar biologi di kelas, baik untuk memahami materi biologi, maupun untuk meningkatkan motivasi belajar biologi di kelas. Meskipun demikian, media-media yang selama ini digunakan di kelas belum secara maksimal mmainkan perannya tersebut

Terkait dengan media pembelajaran seperti apa yang dibutuhkan oleh siswa untuk membuat mereka tertarik belajar, para guru berpendapat bahwasesuai dengan perkembangan zaman, media-media versi teknologi dan informasi (IT), seperti gambar 3D, video, animasi, teknologi yang memanfaatkan perangkat mobile dan internet serta bersifat interaktif. Selain itu, media pembelajaran yang bersifat "mobile" juga diperlukan untuk menunjangkepraktisan agar siswa dapat mengakses informasi di manapun.

Sejalan dengan hal tersebut, para siswa, berdasarkan angket, memiliki tingkat penggunaan smartphone yang tinggi, termasuk penggunaan smartphone sebagai media belajar. Hal ini menunjukkan kedekatan siswa terhadap smartphone yang cukup tinggi karena para siswa banyak menghabiskan waktu dengan smartphone rata-rata $(57.32 \%)$ lebih dari 4 jam setiap harinya. Sebanyak $48.15 \%$ siswa menyatakan bahwa media yang digunakan dalam belajar biologi oleh guru di kelas tidak bervariasi, hanya terbatas pada media-media seperti papan tulis, proyektor, PPT, torso, dan software pelajaran biologi, yang kurang melibatkan para siswa untuk berinteraksi dengan media pembelajaran secara langsung. Para guru, mesikipun mengakui bahwa interaksi siswamedia penting, selain agar siswa tertarik, juga agar banyak yang dapat siswa ingat karena mereka dapat mengaktifkan semua indra, namun mereka memiliki kendala oleh waktu yang terbatas.

\section{Tahapan Prototipe}

Hasil penelitian awal memberikan gambaran bahwa AR versi Android dapat menjadi solusi alternatif sebagai media pembelajaran yang inovatif di kelas. Hal ini dikarenakan AR versi Android memungkinkan siswa untuk mempelajari konten dalam perspektif 3D, memungkinkan pembelajaran di mana saja, kolaboratif dan disituasikan, memvisualisasikan hal-hal yang sulit dilihat, serta menggunakan alat yang akrab dengan siswa sehingga mudah untuk digunakan.

Oleh sebab itu, peneliti mengembangkan media pembelajaran berupa aplikasi AR pada Android untuk konsep sistem eksresi manusia dengan fitur-fitur berupa gambar model ginjal 3D yang disertai dengan keterangan model, dan animasi proses pembentukan urin pada ginjal. Smartphone Android dipilih dalam penyajian teknologi AR selain karena keberadaan smartphone Android yang meluas di sebagian besar siswa $(65.90 \%)$, juga karena kedekatan siswa dengan alat tersebut sehingga akan memudahkan siswa dalam memakainya. Marker digunakan untuk memunculkan objek 3D saat kamera smartphone diarahkan ke marker tersebut dan dibuat agar praktis dan dapat digunakan di mana saja.

Pengembangan media dilakukan setelah sebelumnya dilakukan analisis kurikulum pada silabus yang mengacu pada kurikulum terbaru, yakni kurikulum 2013. Materi yang disajikan pada media ini mengacu pada Kompetensi Inti (KI) dan Kompetensi Dasar (KD) pada silabus Kurikulum 2013.

Selanjutnya media yang telah dikembangkan melalui tahap uji validitas melalui tahapan evaluasi formatif yang terdiri dari evaluasi ahli, evaluasi satu-satu, evaluasi kelompok kecil, dan uji lapangan, untuk dinilai tingkat fungsional media tersebut. Evaluasi ahli dilakukan oleh ahli materi dan ahli media. Berdasakan hasil uji validitas tersebut, media AR versi Android untuk konsep sistem ekskresi manusia tersebut mendapatkan masing-masing skor rata-rata 4 yang dinyatakan valid dan layak untuk dilanjutkan ke tahap penelitian selanjutnya. Demikian juga pada tahapan evaluasi satu-satu, evaluasi kelompok kecil, dan uji lapangan, media AR versi Android untuk konsep sistem ekskresi manusia tersebut mendapatkan rata-rata skor 4 yang berarti media tersebut baik.

Berdasarkan hasil evaluasi formatif, dapat dikatakan bahwa aplikasi AR versi Android 
untuk sistem ekskresi manusia dapat menjadi media pembelajaran alternatif untuk digunakan dalam pembelajaran biologi, baik di kelas (secara formal), maupun di luar kelas (pembelajaran nonformal). Media AR versi Android dinilai mampu untuk digunakan dengan baik dalam pembelajaran biologi di kelas, memiliki keberlanjutan yang baik untuk dapat digunakandalam pembelajaran biologi dalam beberapa jangka waktu ke depan, sesuai untuk digunakan dalam lingkungan pembelajaran biologi,menarik baik oleh siswa maupun guru, serta efektif dalam membantu siswa dalam memahami konsep sistem eksresi manusia.

Dari segi penerimaan dan kemenarikan, rata-rata siswa setuju bahwa media AR versi Android untuk sistem eksresi meningkatkan minat mereka dalam belajar, membuat mereka menjadi lebih bersemangat belajar, membuat belajar menjadi menyenangkan atau menarik, membuat mereka tidak mengantuk ketika belajar biologi, dan membuat materi tentang sistem ekskresi manusia menjadi lebih menarik untuk dipelajari. Hal ini sesuai dengan analisis tentang manfaat AR dalam pembelajaran, yang salah satunya adalah meningkatkan motivasi. Para pengguna AR menjadi lebih berhasrat, tertarik, dan terlibat utnuk berhadapan dengan teknologi baru dan konten belajar mengajar dibandingkan dengan metode non-AR (NAR) (Diegmann, et al, 2015: 1547).

Mereka juga menyatakan bahwa aplikasi $A R$ versi Android untuk sistem ekskresi manusia ini layak untuk dipasang di smartphone mereka, dan mau menggunakannya di smartphone mereka. Gambar 4.16 menunjukkan antusiasme para siswa terhadap aplikasi AR versi Android untuk sistem ekskresi manusia, yang menandakan bahwa aplikasi ini menarik dan dapat diterima oleh mereka.

Menurut mereka, gambar 3D yang ditampilkan inilah yang menjadi daya tarik utama dari aplikasi AR versi Android karena organ sistem eksresi yang selama ini ditampilkan di buku merupakan gambar 2D.Dengan tampilan 3D tampilan organ ekskresi manusia menjadi lebih representatif bagi mereka.AR yang telah diujikan oleh peneliti lain menunjukkan lebih banyak kerincian, terutama di tekstur model (Diegmann, et al, 2015:1549).

Terlebih lagi, untuk memunculkan gambar dan animasi 3D ini teknologi AR menggunakan cara yang tidak biasa bagi mereka, yakni menggunakan marker. Hal ini terbilang baru bagi para siswa untuk digunakan sebagai media pembelajaran sehingga aplikasi ini mampu meningkatkan minat mereka dalam mempelajari sistem eksresi manusia, dan memberikan suasana belajar biologi yang lebih menyenangkan.

Sedangkan dari segi efektivitas, rata-rata siswa setuju bahwa media AR versi Android untuk sistem eksresi membantu mereka untuk memahami dan mengingat materi sistem ekskresi pada manusia, membuat pelajaran biologi lebih mudah dipahami, membantu mereka untuk mengingat materi pelajaran biologi, membantu mereka untuk belajar dengan cara mereka sendiri, serta membantu mereka dalam mengembangkan kreativitas dan imajinasi. Hal ini karena manfaat lain AR dalam pembelajaran dapat membantu meningkatkan konsentrasi siswa (Diegmann, et al., 2015:1548).

Bagi guru, dalam hal kemampuan untuk dilaksanakan, mereka menyatakan menyatakan setuju bahwa aplikasi AR versi Android untuk sistem ekskresi manusia ini sesuai dengan materi, mudah untuk dioperasikan, dan mudah dipahami. Dalam hal kesinambungan, para guru menyatakan sangat setuju bahwa para guru dapat menyesuaikan penggunaan aplikasi AR versi Android untuk konsep sistem eksresi manusia ini dengan kebutuhan di lapangan. Dalam hal keberlanjutan, aplikasi ini oleh guru dinilai memiliki keberlanjutan yang baik untuk dapat digunakan dalam pembelajaran biologi dalam beberapa jangka waktu ke depan. Dalam hal penerimaan dan kemenarikan, media AR ini dapat diterima dengan baik dan menarik untuk digunakan dalam pembelajaran biologi.

Setelah menggunakan aplikasi AR versi Android ini, para guru setuju bahwa media tersebut dapat menjadi solusi alternatif multimedia pembelajaran tentang sistem ekskresi pada manusia. Mereka juga sangat setuju bahwa media tersebut membantu mereka untuk mengajarkan siswa tentang subyek dari pengalaman nyata yang tidak dapat diperoleh siswa secara langsung. Hal ini dikarenakan aplikasi ini menampilkan objek virtual ginjal dalam bentuk 3D yang interaktif seakan-akan model tersebut ada bersama mereka(secara real-time), dipakai langsung oleh siswa, menunjukkan bagian yang lebih detail, dan paktis.

Dalam hal efektivitas, aplikasi AR versi Android ini secara keseluruhan memberikan dampak yang positif bagi guru. Namun ratarata mereka menyatakan ragu bahwa aplikasi 
ini mempermudah dan membantu mereka dalam menjelaskan pelajaran sistem ekskresi pada manusia di kelas. Berdasarkan saran dan masukan yang diberikan pada evaluasi sumatif, para guru mengatakan bahwa akan lebih baik jika guru juga dapat menampilkan objek tersebut di depan kelas menggunakan media seperti proyektor. Meskipun demikian, secara keseluruhan, aplikasi ini diakui oleh mereka dapat membantu para guru untuk mencapai tujuan pembelajaran dengan baik.

Aplikasi AR versi Android untuk sistem ekskresi ini, secara umum, telah menunjukkan bahwa penelitian dan inovasi di bidang teknologi AR dalam pendidikan di Indonesia berpotensi untuk terus dikembangkan, baik dalam hal pengembangan dan penyempurnaan media pembelajaran, maupun dalam hal efektivitas pedagogisnya. Hal ini sesuai dengan Ivanova dan Ivanov, yang menyelidiki manfaat teknologi AR pada sektor pendidikan sebagai teknologi yang menjanjikan dan efektif yang dapat memberikan pemahaman yang lebih baik tentang teori dan fakta (Ivanova \& Ivanov, 2011:176).

\section{Keterbatasan Media Augmented Reality Versi Android untuk Konsep Sistem Ekskresi Ma- nusia}

Aplikasi augmented reality versi Android untuk sistem ekskresi manusia ini memiliki memiliki memory sebesar 25.3 MB dan menggunakan memory cukup besar pada handphone, yakni sebesar 45.60 MB. Untuk perangkat dengan fitur yang memadai, hal ini tidak menjadi masalah besar. Namun bagi perangkat dengan kapasitas memory yang kecil, terdapat beberapa kendala untuk menjalankan aplikasi ini, seperti HP menjadi lag, cepat panas dan baterai handphone lebih cepat habis.Keterbatasan tersebut pula yang membuat aplikasi AR versi Android untuk konep sistem ekskresi manusia ini memuat tidak terlalu banyak konten dan detail.

\section{SIMPULAN}

Media pembelajaran augmented reality (AR) versi Android untuk konsep sistem ekskresi manusia dapat diterima dengan baik dan dinilai mampu untuk digunakan dengan baik dalam pembelajaran biologi di kelas, memiliki keberlanjutan yang baik untuk dapat digunakandalam pembelajaran biologi dalam beberapa jangka waktu ke depan, sesuai untuk digunakan dalam lingkungan pembelajaran biologi, menarik oleh siswa dan guru sekolah menengah atas di Jakarta Selatan sebagai media belajar pada konsep sistem ekskresi manusia. Bagi siswa dan guru, gambar $3 \mathrm{D}$, sistem penggunaan marker sebagai penampil objek, animasi, dan musik latar pada aplikasi AR versi Android tersebut merupakan hal-hal utama yang menjadi daya tarik bagi mereka.

Dalam hal pedagogis, media pembelajaran AR versi Android untuk konsep sistem ekskresi manusia ini secara efektif dapat membantu guru dan siswa dalam pembelajaran biologi, khususnya pada konsep sistem ekskresi manusia. Dengan media tersebut, siswa dapat terbantu untuk memahami konsep sistem ekskresi manusia dengan baik, dan guru dapat terbantu untuk mencapai tujuan pembelajarannya dengan baik.

Penelitian ini memiliki beberapa keterbatasan yang perlu ditangani dalam penelitian yang akan datang. Beberapa siswa dan guru menunjukkan bahwa keterbatasan pada perangkat keras dan perangkat lunak yang digunakan menyebabkan lamanya waktu yang dibutuhkan untuk memuat beberapa konten pada aplikasi tersebut. Seiring dengan pengembangan yang dilakukan oleh pengembang platform, masalah terkait dengan kemudahan penggunaan aplikasi tersebut akan dapat teratasi.

\section{UCAPAN TERIMA KASIH}

Ucapan terima kasih disampaikan kepada sejawat dan semua pihak yang telah membantu penelitian ini. Mudah-mudahan semua itu diperhitungkan sebagai amal yang bernilai pahala. Amin.

\section{DAFTAR PUSTAKA}

Aprilianti, Dian. 2013. "Perbandingan Hasil Belajar Siswa dengan Menggunakan Model Pembelajaran Kooperatif Tipe Jigsaw dan Numbered Head Together (NHT) pada Sub MateriPokok Sistem Ekskresi di Kelas XI SMA Swasta Nur Azizi Tanjung Morawa TP.2012/2013". Skripsi. Medan: Universitas Negeri Medan. Tidak dipublikasikan.

Chen, Da-Ren, Chen, Mu-Yen, Huang, ThienChi, \& Hsu, Wen-pao. 2013. "Developing a Mobile Learning System in Augmented Reality Context". International Journal of Distributed Sensor Networks, 2013, pp.1-7. 
Diegmann, Phill, Schmidt-Kraepelin, Manuel, Eynden, Sven Van Den, \& Basten, Dirk. 2015. "Benefits of Augmented Reality in Educational Environments - A Systematic Literature Review". 12th International Conference on Wirtscahftsinformatik, Osnabruck, pp. 1542-1556.

Hasruddin. 2009. "Peran Multimedia dalam Pembelajaran Biologi”. Jurnal Tabularasa PPS Unimed, 6, pp.149.

Ivanova, Malinka \& Ivanov, Georgi. 2011. "Enhancement of Learning and Teaching in Computer Graphics Through Marker Augmented Reality Technology". International Journal on New Computer Architectures and Their Applications (IJNCAA), 1, pp. 176 and 183.

Pribadi, Benny A. \& Katrin, Yuni. 2004. Media Teknologi. Jakarta: Universitas Terbuka. hlm. 1.3.
Primasari, Rosita. 2014. "Penggunaan Media Pembelajaran oleh Guru Biologi”. Skripsi. Jakarta: UIN Syarif Hidayatullah, hal.52, tidak dipulikasikan.

Smaldino, Sharon E. et al. 2011. Instructional Technology \& Media for Learning. Jakarta: Kencana.

Yuen, Steve Chi-Yin et al. 2011. "Augmented Rea-lity: An Overview and Five Directions for AR in Education". Journal of Educational Technology Development and Exchange, 4(1), pp. 132.

Zulkardi.2009. Formative Evaluation: What, Why, When, and How.http://www.oocities.org/zulkardi/books.html. diunduh 30 April 2015. 